\title{
Etnographie-Semiotic of Sigale-Gale's Legend in Samosir Lake, North Sumatera, Indonesia
}

\author{
Nensy Megawati Simanjuntak \\ Indonesian Language and Literature Education \\ Surabaya State University \\ Surabaya, Indonesia \\ nensymegawatisimanjuntak2406@gmail.com
}

\begin{abstract}
Indonesia has a diverse culture, among cultures that are one of the unique culture, unique, and interesting to study. Not only culture, this area is also rich in natural pemandagangan and customs. Samosir Island is an island inhabited by the Toba Batak. Batak Toba Batak different from the other. Batak Toba has legends and folklore are quite a lot and the legends are full of value, functionality, and signs. Cultural values are very closely related to the agreement and traditions that exist in the region. None of the cultures in Indonesia, which does not have a function. All co-exist and complement each other. In cultures that there will be a sign that symbolizes something. These are signs in the legend " Sigale -gale " on the island of Samosir, North Sumatera .Oral art intrinsically is the tradition had bay a group of certain society. Its existence is confessed, even very close with society group that owning it. In oral art, its story content oftentimes lay open situation of social cultural of society bearing it. Usually oral art contain in the form of social background picture, culture, and artisty drawn in Sigale- Gale story. Two focus that discussed in this research: (1) How are the cultural values in the legend of Batak Toba Sigale-gale on Samosir Island, North Sumatra? (2) How cultural functions contained in Sigalegale legend on the island of Samosir, North Sumatra? and (3) How to sign contained in Sigale legend gale on the island of Samosir, North Sumatra? As approach which used in this thesis research is art antropoloy, by exploiting structural theory as structural text analysis foundation, culture theory to analyze cultural concept of Batak Toba society which there in Sigale-Gale story. Result of research of Sigale-gale story indicate that Batak Toba society in Samosir reveal that special target of life of Batak Toba society at former epoch, that is each and everyone have a mind to reach hamoraon (properties), hagabeon (offspring) and hasangapon (honorary). Special regarding to the target of life to get blessinh through offspring (that hagabeon), in the view of traditional Batak society that owning many child is importance. Batak Toba society that embracing patrilineal consanguinity sistem, boys have important meaning in life of family. Family which does not have boy supposed tree which do not hava root. Every boy have obligation to manage and continue the continuity of family life. Batak society wish the ideal death according to death custom, which goal by every member of Batak Toba society, that is have old age, bearing to have, grandchild and cheeping. All its clan gabe (have many clan) and maduma (secure and prosperous life), there's no handicap and inveigh. That death referred as saurmatua.
\end{abstract}

Keywords-oral art intrinsically; Sigale-gale; the cultural values; the cultural function; sign contain

\section{INTRODUCTION}

\section{A. Background}

Culture dominated the conversation throughout the century. Not only in the social sciences of humanities, but also the science of depth. The broadest definition perceives culture as all human activity, concrete or abstract, both with positive or negative goals. This definition was first put forward by E.B Taylor in his book Primitive Culture (1871). To find out the intellectual community receptions to the diversity of cultural understanding, Krober and Kluckhohn managed to collect as many as 160 cultural definitions.

Every conversation about culture is generally associated with national culture and regional culture. In order to preserve the unity and integrity of the nation, national culture is regarded as the tops of regional culture, the highest level of the realization of the result of creation, taste, and initiative of society. Regional culture thus serves to sustain, motivate the development of national culture, and so on. Indonesian language, the symbol of the State, the national anthem, the Youth Pledge, etc., including national food and clothing, are considered national identities that serve as the binding of national unity [1, p. 153].

According to Santos, in the era of globalization, especially with the entry of various forms of foreign culture on the one hand, the dissemination of aspects of national culture belongs to the world on the other. Given such a phenomenon, the national cultural scope of libraries needs to be expanded, ie on the world culture, in this connection of Western culture. Global culture seems to have become one with national culture, as glonal (globali national) and glocal (local globa). As an additional note for further consideration, with different arguments, even diametrically opposed, human civilization originates in the east, namely Indonesia.

According to Statda, Taput, North Sumatra Province is located at $1^{\circ}-4^{\circ}$ North Latitude and $98^{\circ}-100{ }^{\circ}$ East Longitude, The Area of North Sumatera Province is 72,981.23 
$\mathrm{km}^{2}$. North Sumatra basically can be divided into: East Coast, Bukit Barisan Mountains, West Coast, Nias Island East coast is the most rapidly growing province within the province due to relatively more complete infrastructure requirements than other areas. The eastern coastal region is also a relatively densely populated area compared to other regions.

The myth and history of Toba Batak deployment [2, p. x] cannot be separated unequivocally. Batak Toba people who have undergone modern education are most likely no longer fully accept the truth of the mythological description of the history of the development of his tribe. But, after all, they will appreciate the origin of their ancestors. The basic concept in the Toba Batak kinship organization is the clan. Marga is a group of people who are descended from a grandfather together, and the lineage is counted through the father (patrilineal patrilineal).

All members of one clan wear an identity after their first name, and the name of the clan is a sign that those who use it still have the same grandfather. Probably, there can be no more details of the order of grandfathers who linked the clans to their grandparents with so many generations ago, but there is a belief that people who use the same clan names are intertwined by blood relationships, one consequence is the prohibition of bonding for women and men with the same surname. The kinship system is the main joint in Toba Batak culture [2, pp. $\mathrm{x}-\mathrm{xi}$.

According to Suwardi Endraswara, oral literature is a work that spread is delivered from mouth to mouth for generations [3, p. 151]. Because of its spread from mouth to mouth, much of the oral literature fades because it can not be maintained. In addition to the limitations of human memory in remembering, the increasingly sophisticated technological developments in the current era of globalization have shifted oral literature that ever existed, including the oral literature of the Batak Toba community that has high cultural values, which should be preserved.

The Toba Batak oral literature can be viewed as an important and valuable cultural asset worthy of study and conservation [4, p. 1]. A part of the Toba Batak oral literature is still applied in the community's customs. Mite (myth), legend (legend), and fairy tale (folklore), is a genre of people's prose who once lived in Batak Toba society. Mite is an old story that is often associated with gods or supernatural powers that exceed the limits of human capabilities expressed in the occult and considered sacred.

Legend is an ancient folklore that has to do with historical events but is not considered sacred, and fairy tales are people's prose that is not considered to be true by the owner of stories and tales not bound by time and place (Bascom in [5, p. 50]). But if studied in depth, it turns out the legend has a deep understanding, there are views of life, religious life, and the sacred world of society. Some individuals in society trust the legend as the guide of his life.
The human curiosity to understand something behind the legend grew stronger, an event that depicts the history and moral values contained within it and almost all legends have mystical things. Thus, through the literary work found the pattern of kinship relationships, behavior, beliefs and everything that lives and become a tradition in the society [4, p. 5]. Through literary works that are also created as one of the cultural products of course can bridge to arrive at the understanding or at least open attitude to appreciate the various ethnink culture in the archipelago. Because the researchers participated openly in the appreciation of literature, the researchers are interested to study the oral literature in Batak Toba. The main foundation in this study is to examine the main nonmaterial cultural values in the Toba Batak oral literature "Sigale-gale".

Sigale-gale is one of the oral stories possessed by the Batak Toba community, originating from Silalahi or "Tao Silalahi", a relic of Oppungku Raja Silahisabungan, recorded on the Dutch map, at the time of the Dutch colonial in 1832 with the old spelling named Tao Silalahe. While the inauguration Silalahi recorded on the construction of the monument King of Silahisabungan which was inaugurated on 23-27 November 1981. The story "Sigale-gale" has a value model role that can be applied in human life. Sigale-gale is a form of trial in Silalahi society that emphasizes the aspect of honesty.

The interest of writers in taking the legend of Sigale-gale, besides having the value of role model, not all individuals or Batak Toba people who know the oral story, for that researchers want to introduce it so that the story is not extinct. According to Olrik in Sukatman, the extinction of oral tradition is caused too long not to be remembered by the community and never be heard again. Because the oral literature is increasingly faded and based solely on the memory of the speaker so as to alter the authenticity of an oral literature, the researcher is interested in studying it and then documenting it, the hope to be achieved in this research can make the oral literature into an ever-living and sustainable literature.

Based on the description, this paper is intended to analyze the existing marks on the traditional dance "Sigale-gale" originating from Batak Toba tribe, North Sumatra. This study analyzes the sign in the legend "Sigale-gale".

Semiotics became one of the studies that even became a tradition in communication theory. The semiotic tradition consists of a set of theories about how signs represent objects, ideas, circumstances, situations, feelings and conditions outside the signs themselves. Semiotics aims to know the meanings contained in a sign or interpret the meaning so it is known how communicators construct messages.

The concept of meaning is inseparable from certain ideological perspectives or values as well as cultural concepts into the realm of community thought in which the symbols are created. Cultural codes that are one of the factors of constructing meaning in a symbol become an important aspect 
to know the construction of messages in the sign. This construct of meaning is formed which then becomes the basis of ideological formation in a sign. As one study of thought in cultural studies, semiotics must see how culture becomes the basis of thought of the formation of meaning in a sign. Semiotics study the systems, rules, conventions that allow them to have meaning.

\section{B. Problem Formulation}

Based on the background that has been described above, this study has some formulation of the problem, namely: How is the sign contained in the legend Sigale-gale on Samosir Island, North Sumatra?

\section{Research Objectives}

Based on the formulation of the problem, this study aims to describe the sign contained in the legend Sigale-gale on the island of Samosir, North Sumatra.

\section{DISCUSSION}

\section{A. Symbol or Sign}

According to Meliono and Budianto, along with the development and progress of human thinking, developing the process of relationship in seeing the symbol. Symbols are not just a sign but a system full of transformation to find creativity, can even become more communicative symbols. Man becomes wise in connecting the symbols with what he wants, and he becomes more intelligent in understanding it as well. Human understanding of the symbols used requires one to think clearly in formulating symbols [6, p. 26].

Hartoko and Rahmanto in his Guide in the World of Literature define the symbols as follows: The symbol of the Greek word "sym-ballein" which means toss together. An object is said with an idea. Usually symbols occur based on metonymy and metaphorical. Distinguished symbols: universal symbols, cultural symbols, and individual symbols.

\section{1) Hamoraon}

In the Sigale-gale story, the concept of hamoraon is very strongly seen in Datu Panggana, Bao Partigatiga and Datu Partoar characters, especially Nai Manggale figures, as a family with no children. Above has been mentioned wealth is measured not only wealth, but the number of children. However, in the Sigale-gale texts, Datu Partoar has boru though only boru lift. Still, the lineage of each character will be disconnected because it does not have a biological child.

In the socio-cultural phenomenon of Batak Toba, the mission of the life of mamora (rich) or hamoraon (wealth), not only measured by the material alone, but also the number of descendants. In Batak culture, traditionally, also formulated the main purpose of life of Batak society, which reaches hamoraon (wealth), hagabeon (offspring), and hasangapon (honor). Especially about the purpose of life to get the blessing through the hagabeon (heredity), in view of traditional Batak society has many children is very important.
In many marriages ceremonies are always expressed blessings pleading for couples given the gift of many descendants: maranak sappulu pitu (have 17 son), marboru sappulu onom (have 16 daughters).

\section{2) Hagabeon}

In the Sigale-gale story, the concept of hagabeon is clearly illustrated. Datu Panggana and Datu Partiktik strive to achieve the agreed concept of hagabeon. The efforts undertaken by Datu Panggana and Datu Partiktik is one of the symbols expected every individual Batak Toba society.

"Years have passed, but Nai Manggale and Datu Partiktik have no children. They had gone from one shaman to another, but Debata did not seem to grant their intentions. Even Datu Partoar, known for his miracle cures is powerless in this regard. (Sigale-gale, 1978: 50)

Hagabeon is a family condition that is endowed with the offspring of the sons and daughters, but the meaning of the philosophy does not end there. Hagabeon can still be interpreted to gain many grandchildren, even greatgrandchildren.

In the Batak Toba community, the concept of hagabeon is expressed in marital relationships. The word hagabeon is the key word of the context of marriage, although it is still a hope, namely: presumably descend many sons and daughters, and live long to enjoy the life of a funny atmosphere.

These hopes are philosophically regarded as prayers. So great is the meaning of hagabeon that is often applied for the phrase: maranak sappulu pitu, marboru sappulu onom, meaning with 17 boys and 16 girls, which means 33 children, the numbers that symbolize the many generations. Uniquely, until now generally still embraced Batak Toba community, although every family has been criticizing such thinking at this time.

\section{3) Hasangapon}

In the phenomenon of Batak Toba society life, hasangapon is an accumulation of honor, dignity, self esteem, or charisma of a person, but hasangapon supported hagabeon and hamoraon. In this case, the figure of Datu Partiktik who has not yet had children, will be extinguished the rays of honor of his family as reflected in the following quotation:

"Nai, know, that must be Partictic Datu must be more sorrowful again, because with no children, means no one to continue the clan Datu. The cessation of clan inheritance means that the family's rays of honor will be extinguished. This is very piercing the heart of a Batak man.

As a philosophy of life, the hasangapon certainly not limited to individual or individual criteria, but can be accepted and apply collectively. The meaning of hasangapon in the collective order is more emphasized on the honor or selfesteem in a community bond. 


\section{4) Sarimatua and Saurmatua}

One of the happiness coveted by every Batak people is to reach saurmatua age. While sarimatua is the level of age and condition of a person when the elderly, has had sons and daughters and has had grandchildren, but not all sons and daughters have married, there are still unmarried. The term sarimatua consists of two words "sari" and "matua". Sari means there are still things to be done, matua means old age. So, sarimatua is elderly, but there is still something to marry. While saurmatua is the level of age and condition of a person when the elderly, has reached the level or the state already has sons and daughters who all have a family and also has had grandchildren. More ideal, if he has a great grandchild (nini and nono). One of the happiness coveted by the Batak people is to be able to reach the age of saurmatua.

\section{5) Papurpur Sapata}

Sigale-gale's story closely related to the type of death. The death of Nai Manggale requires that a sapata papurpur ceremony be performed by a Sigale-gale statue. Marbun and Hutapea define six types of death in the Toba Batak culture: (1) Mate Mangkar: a husband or wife who died before a grandchild, his sons and daughters have not married, (2) Mate Ponggol (mate matipul): died young and unmarried, (3) Mate Punjung: died in a land of people, where no relatives, (4) Mate Punu: died without leaving sons, but princess only, (5) Mate Pupur: died in the world without any offspring both son and daughter, and (6) Mate Tompo: died suddenly [7, pp. 105-106]. Based on some understanding above it can be concluded that there are elements associated with papurpur sapata ie mate punu. Sapata is a curse. In the past when someone feels damned, then to eliminate the ceremony held papurpur sapata, which is a particular release held as an attempt to remove the sapata. Nai Manggale as the main character also condemns her husband Datu Partiktik has no children, although married to another woman. To prevent such rights, Datu Partiktik must fulfill Nai Manggale's request, which is to make a wooden statue of human body and be named Sigalegale.

\section{6) Ulos}

Ulos is not explicitly described but is implied in the Sigalegale text. Batak society is never separated from ulos, both in the show of love and sorrow. Ulos is a special kind of cloth woven with its own motifs. The motifs and colors of the fabric contain special meanings as well, and are not found in any custom event. According to [8, p. 92], ulos holong for Batak people who died, there are various legal provisions. In Sigalegale who receives ulos there is a young child who dies / If a child dies (not married) then there is no show of handling. If the deceased is a married person, after hula-hula hear khabar about this, is provided a ulos for tujung and the bone provides ulos membrane. Giving along with the words of sorrow (marhabot ni roha). After a few days later, followed by opening event (revealing) tujung done party hula-hula. After the corpse is buried, at that time there is also carried out reveal the tujung, depending on the agreement of both parties.
Hula-hula provides rice dipiring (warden ni tondi), clean water for washing face (aek parsuapan), water one glass (aek sitio-tio). Implementation of the event revealed tujung generally made in the morning (panangkok ni mata ni ari). After the party hula-hula open tujung from the balu, followed by washing face (marsuap). The abandoned children also washed their faces, followed by sowing of rice on their heads and children. A Batak philosophy says: Ijuk pangihot ni hodong, ulos pangihut ni holong, meaning: ijuk is a binder of stem on the trunk and ulos is a binder of love saying between parents and children or between someone with others. A certain release that was held as an attempt to remove the sapata. Nai Manggale as the main character also condemns her husband Datu Partiktik has no children, although married to another woman.

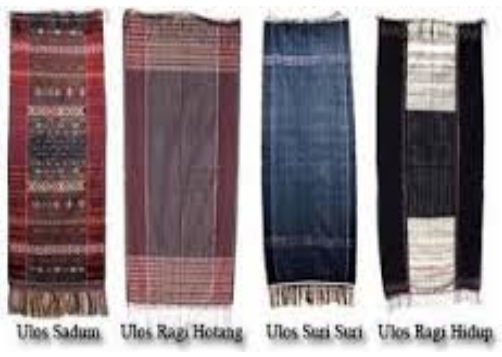

Fig. 1. Ulos.

\section{REFERENCES}

[1] N. K. Ratna, Penelitian Sastra: Teori, Metode, dan Teknik [Literary Research: Theories, Methods, and Techniques]. Yogyakarta: Pustaka Pelajar, 2004

[2] J. C. Vergouwen, Masyarakat dan Hukum Adat Batak Toba [Society and Customary Law of Batak Toba]. Yogyakarta: Lkis Pelangi Aksara, 2004.

[3] S. Endraswara, Metodologi Penelitian Sastra [Literary Research Methodology]. Yogyakarta: Pustaka Widyatama, 2003.

[4] Nurelide, "Meretas Budaya Masyarakat Batak Toba dalam Cerita Sigalegale [Entering the Batak Toba Society Culture in the Story of Sigalegale],” Master's thesis, Literary Science, Diponegoro Univ., Semarang, Indonesia, 2007.

[5] J. Danandjaja, Folklore Indonesian: Ilmu gosip, Dongeng, dan lain-lain [Indonesian Folklore: Gossip knowledge, Fairytale, et cetera]. Jakarta: Graffiti Press, 1984.

[6] I. Meliono and Budianto, 2004. Ideologi Budaya [Culture Ideology]. Jakarta: Yayasan Kota Kita, 2004.

[7] M. A. Marbun and I. M. T. Hutapea, Kamus Budaya Batak [Batak Culture Dictionary]. Jakarta: Balai Pustaka, 1987.

[8] E. H. Tambunan, Sekelumit Mengenai Masyarakat Batak Toba dan Kebudayaannya Sebagai dan Sarana Pembangunan [A Little about Batak Toba Society and its Culture as the Tool of Development]. Bandung: Tarsito, 1982. 